\title{
Prophylactic Effect of Cyperus Esculentus Milk on High Dose Acetaminophen Model of Hepatic Toxicity in Wistar Rats
}

\author{
*D.I. Akinloye, A.P. Adejumo, O.A. Akinloye \\ Department of Biochemistry, College of Biosciences, Federal University of Agriculture, Abeokuta, Nigeria \\ [Corresponding Author: E-mail: akinloyedi@funaab.edu.ng; Z: +2348069152065]
}

\section{ABSTRACT}

Cyperus esculentus is a wholesome nut with notable nutritional and medicinal benefits. This study investigated the prophylactic impact of Cyperus esculentus milk extract (CE) on high dose acetaminophen (APAP)-induced liver impairment in experimental rats. Thirty rats weighing between 180-200 g were randomly distributed into 6 groups $(n=5)$. Groups 1 (control given only distilled water) and 2 (negative control given APAP) were without treatment, while rats in groups $3,4,5$ and 6 were orally administered $8.57 \mathrm{mg}$ ascorbic acid, $100 \mathrm{mg} / \mathrm{kg}, 200 \mathrm{mg} / \mathrm{kg}$ and $400 \mathrm{mg} / \mathrm{kg}$ of body weight CE respectively for 21 days. On the 22nd day of the experiment, $1 \mathrm{~g} / \mathrm{kg}$ body weight of acetaminophen was administered orally to rats in groups $2,3,4,5$ and 6 . The serum and liver of sacrificed animals were collected for analyses. CE at selected doses appreciably prevented high dose acetaminophen-induced increase in serum activities $(p<0.05)$ of alanine aminotransferase (ALT), aspartate aminotransferase (AST), alkaline phosphatase (ALP), and concentration of malondialdehyde as seen in the untreated APAP control group. Decreased serum GST activity caused by acetaminophen in untreated group improved significantly $(p<0.05)$ in CE treated groups which was comparable $(p>0.05)$ to ascorbic acid group. In the liver, acetaminophen decreased the activities of AST, ALT, ALP, however, increased concentration and activity of malondialdehyde and GST respectively $(p<0.05)$. Pre-administration of CE markedly prevented these effects in the liver of rats that were administered acetaminophen. The present study demonstrated $C$. esculentus milk extracts prevented hepatic damage caused by high dose acetaminophen in rats.

Keywords: Acetaminophen, Cyperus esculentus, biomarkers, hepatoprotective.

\section{INTRODUCTION}

Liver is the largest functional organ of the body that is crucially involved in metabolism, secretory, detoxification and elimination. Acetaminophen ( $\mathrm{N}$-acetyl-p-aminophenol, paracetamol, APAP) is often used as an antipyretic and analgesic drug. It is known to cause acute liver toxicity even when used at therapeutic dose (Craig et al., 2012; Urban et al., 2014; Major et al., 2016). Primarily, metabolism of acetaminophen involves reduction to nontoxic metabolites. However, about $5 \%$ is transformed in the liver by the cytochrome P450 family to N-acetyl-pbenzoquinone imine. This product covalently bind sulfhydryl groups from glutathione, thereby causing depletion of the glutathione, $\mathrm{N}$-acetyl-pbenzoquinone imine further binds to hepatocyte proteins, leading to hepatic toxicity. The biochemical features of hepatic damage become apparent within 20-50 hours after acetaminophen overdose (Adewusi and Afolayan, 2010; Major et al., 2016).

Clinical data strongly recommended antioxidant supplements as promising therapeutic means of managing liver toxicity (Medina and MorenoOtero, 2005). Despite the increasing discoveries in modern medicine, there are few drugs or compounds that offer protection to the liver or help to revivify hepatic cells (Adewusi and Afolayan, 2010). Some of these drugs used are not devoured of serious adverse effects which may affect liver (Ozougwu, 2011) Therefore, there is increasing interest on medicinal plants endowed with bioactive antioxidants capable of protecting against oxidative damage of the liver.

Cyperus esculentus (tiger nut sedge) belong to species of sedge, usually cultivated in the 
northern part of Nigeria. Cyperus esculentus is rich in vitamin B1, which assists in central nervous system coordination (Mokady and Dolev, 1970). The black species of the $C$. esculentus is used for management of breast cancer (Arafat et al., 2009). The tubers hold a high total antioxidant capacity, because they hold notable amounts of water-soluble flavonoid glycosides (Eteshola and Oraedu, 1996). The genus Cyperus are wellknown for their richness in essential oil (Couchman et al., 1964) monounsaturated fatty acid content and appreciable vitamin $E$ levels. $C$. esculentus have been suggested to be a valuable nutritional therapy for cardiac pathologies due to its Oleic acid contents (Eteshola and Oraedu, 1996; Hassanein et al., 2011). C. esculentus oil has been delineated to have positive reverberation on digestive secretions, which is also attributed to high content of oleic acid, a potent stimulator of production of Cholecistokinine (Couchman et. al., 1964).

In addition, essential oil obtained from $C$. esculentus tubers have been shown to exhibit in vitro hepatoprotective effects against acetaminophen on a culture of monolayer of rat hepatocyte (Hassanein et al., 2013). In China and Spain, C. esculentus milk is used an aphrodisiac and in the management of liver impairment, heart diseases, stomach pain and menstruation (Sanchez-Zapata et al., 2012; Yang et al., 2016). The present study focused on evaluating the hepatoprotective potential of Cyperus esculentus milk extract on acetaminophen (APAP) induced liver toxicity in experimental rats.

\section{MATERIALS AND METHODS}

\section{Chemicals}

Chemicals used for this study were of analytical grade. Acetaminophen was obtained from Evans Medical PLC., Nigeria, and Ascorbic acid from Tuyil Pharmaceuticals, Nigeria. Assay kits for liver function tests were purchased from Randox Laboratory, United Kingdom.

\section{C. esculentus Milk Extraction}

Dried C. esculentus tubers were sorted and 300 $\mathrm{g}$ was grinded and soaked in $1000 \mathrm{ml}$ of distilled water for 24 hours, filtered using muslin cloth to obtain the milk extract. The filtrate was concentrated in a microwave at $40^{\circ} \mathrm{C}$ to yield $13.95 \mathrm{~g}$ of the plant milk in powdered form (Ahmed \& Ramaswamy, 2004). The powdered milk extract was stored in an air-tight plastic container until required.

\section{Experimental Design and Animal Grouping}

Thirty male albino rats weighing between 180 $200 \mathrm{~g}$ procured from the College of Veterinary Medicine, Federal University of Agriculture, Abeokuta. were housed in a plastic-wired cage and allowed to acclimatized at the Animal house, College of Biosciences, Federal University of Agriculture, Abeokuta (FUNAAB) for a period of two weeks prior to the commencement of the study. They were allowed access to feed adlibithum. The rats were randomly divided into six groups ( $n=5$ per group). Group 3 received 8.57 $\mathrm{mg} / \mathrm{kg}$ bw ascorbic acid (standard control), Group 4: $100 \mathrm{mg} / \mathrm{kg}$ bw Cyperus esculentus milk (CE); Group 5: $200 \mathrm{mg} / \mathrm{kg}$ bw Cyperus esculentus milk and Group 6: $400 \mathrm{mg} / \mathrm{kg}$ bw Cyperus esculentus milk. Treatment lasted for 21 days and on the $22^{\text {nd }}$ day of the experiment, the rats in group 2,3,4,5 and 6 were orally administered high dose acetaminophen ( $1 \mathrm{~g} / \mathrm{kg}$ body weight) and fasted for 24 hours. Group 1 served as healthy control group while Group 2 was the negative control which received no treatment.

\section{Blood sample and tissue collection}

Blood sample was collected via cardiac puncture, centrifuged at $4000 \mathrm{rpm}$ for 15 minutes to obtain serum which was stored at $-20^{\circ} \mathrm{C}$ for biochemical analysis. The rats were anaesthesized, and part of the liver was excised, washed in $1.15 \% \mathrm{KCl}$ and homogenized in Tris- $\mathrm{HCl}$ buffer, the homogenate was centrifuged at 10,000 rpm for 10 minutes and the supernatant was stored at $20^{\circ} \mathrm{C}$ prior to biochemical analysis. 


\section{Biochemical Analysis}

Markers for assessing hepatocyte integrity - ALT and AST - were estimated by method of Reitman and Frankel (1957), ALP was estimated with method described by Otto et al. (1946). Lipid peroxidation by-product malondialdehyde (MDA) was determined using method of Buege and Aust (1978). Activity of glutathione-S-transferase (GST) was carried out as described by Habig et al (1974). All these biochemical analysis were carried out both in the serum and liver homogenate.

\section{Histopathological Studies}

Part of the liver excised from the rats were rinsed with buffer and immediately fixed by perfusion using $10 \%$ formalin and $10 \mathrm{mmol} / \mathrm{L}$ phosphate buffer $\mathrm{pH} 7.4$ at $4^{\circ} \mathrm{C}$ for 12 hours. The tissue was then embedded in paraffin after dehydration, cut into sections, stained with hematoxylin-eosin dye on glass slides and was further processed into micrographs. The photomicrographs were obtained with light microscope.

\section{Data analysis}

The generated data were analyzed using Graphpad prism 6.04 (GraphpadSoftware Inc, USA). Each parameter was compared in the groups using one way analysis of variance (ANOVA) and tukey's multiple comparison test was used to identify differences between means. Differences at $p<0.05$ were considered to be statistically significant.

\section{RESULTS}

Cyperus esculentus milk on acetaminophen alteration in liver enzyme activitities

Overdose of acetaminophen $(1 \mathrm{~g} / \mathrm{kg})$ caused significant increase $(p<0.05)$ in serum AST activity when compared to normal group (group A), ascorbic acid prevented this effect by reducing AST activity beyond the normal group while $200 \mathrm{mg} / \mathrm{kg}$ bw and $400 \mathrm{mg} / \mathrm{kg}$ bw administered CE mitigated the effect of acetaminophen on AST which is not significantly different $(p>0.05)$ from ascorbic acid treated group (Figure 1a). Acetaminophen causes marked decrease in AST activity in the liver, this effect was not seen in $200 \mathrm{mg} / \mathrm{kg}$ bw and 400 $\mathrm{mg} / \mathrm{kg}$ bw CE treated groups. The extract showed a dose dependent mitigation of acetaminophen effect on liver AST activity (Figure 1b). Figure 2a shows increased in the serum ALT activity $(p<0.05)$ in group administered high dose acetaminophen, while it reduces ALT activity in the liver (Figure 2b), in both case the effects were mitigated by ascorbic acid and CE at different doses, though dose dependent mitigation of acetaminophen effect by CE extracts was observed in the liver alone. High dose acetaminophen significantly $(p<0.05)$ increased ALP activity in the liver likewise in the serum, however, selected doses of CE prevented the effect caused by acetaminophen in serum and liver, and dose related changes were observed in ALP activity in the serum (Figure 3a and b).
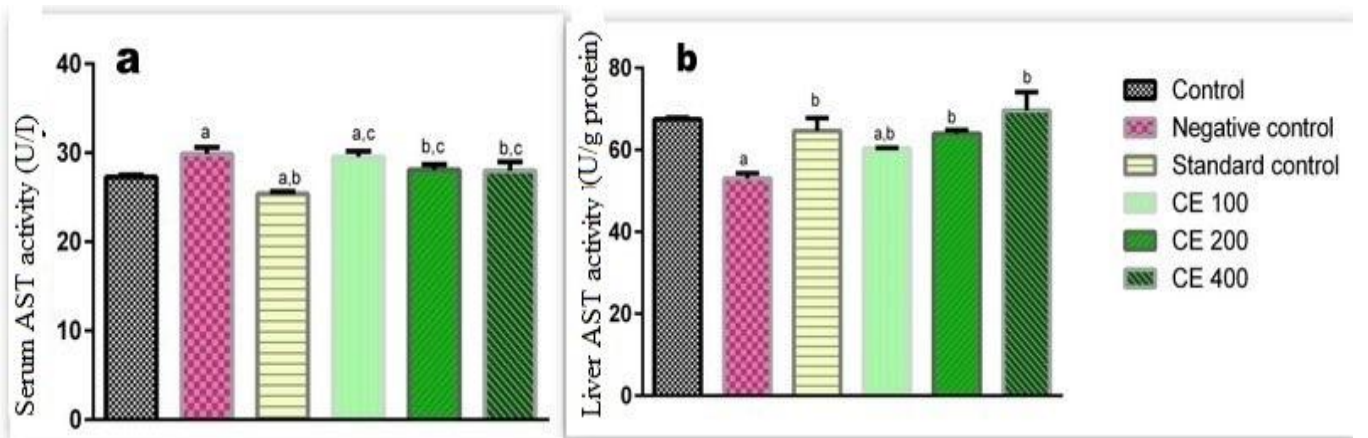

Figure 1: Effect of Cyperus esculentus milk extract on serum (a) and liver (b) AST activity.

aSignificant when compared with control at $p<0.05$, ${ }^{\circ}$ Significant when compared to negative control at $p<0.05$, ${ }^{\circ}$ Significant when compared to standard drug at $p<0.05$. Control: No treatment, Negative control: APAP 1 $\mathrm{g} / \mathrm{kg}$, Standard control: pre treated with 8.57mg/ kg Ascorbic acid, CE 100: pre administered $100 \mathrm{mg} / \mathrm{kg}$ CE, CE 200: pre administered $200 \mathrm{mg} / \mathrm{kg} \mathrm{CE}$, and CE 400: pre administered $400 \mathrm{mg} / \mathrm{kg}$ CE 

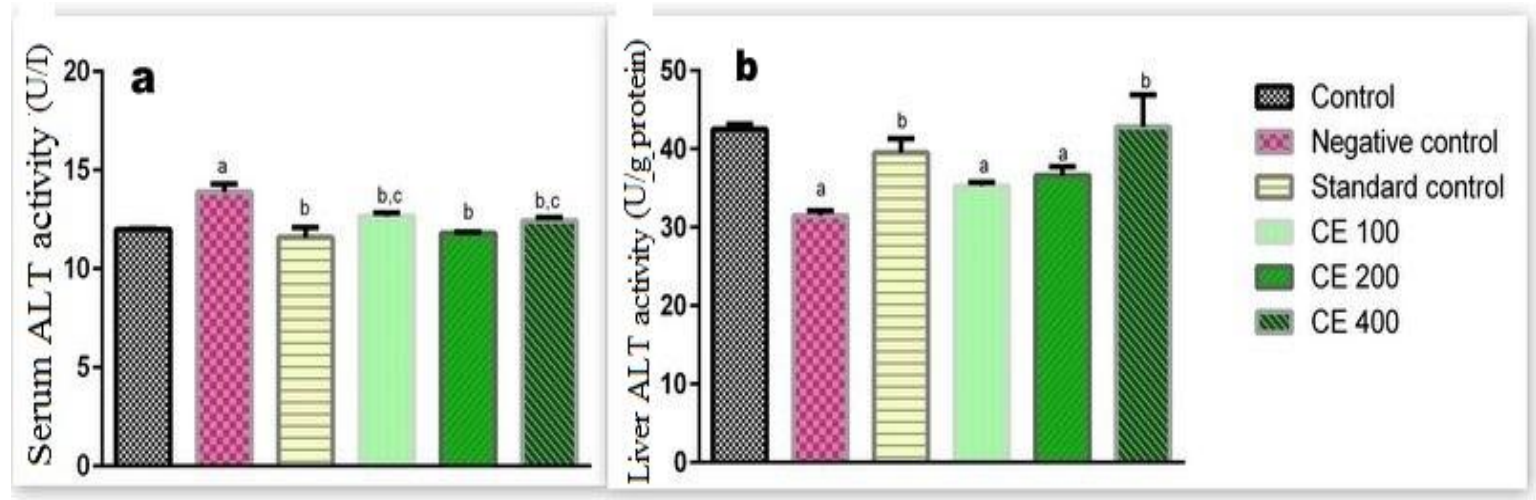

Figure 2: Effect of Cyperus esculentus milk extract on serum (a) and liver (b) ALT activity

aSignificant when compared with control at $p<0.05$, ${ }^{b}$ Significant when compared to negative control at $p<0.05$, ${ }^{\circ}$ Significant when compared to standard drug at $p<0.05$. Control: No treatment, Negative control: APAP 1 $/ \mathrm{kg}$, Standard control: pre treated with $8.57 \mathrm{mg} / \mathrm{kg}$ Ascorbic acid, CE 100: pre administered $100 \mathrm{mg} / \mathrm{kg} \mathrm{CE}$, CE 200: pre administered $200 \mathrm{mg} / \mathrm{kg} \mathrm{CE}$, and CE 400: pre administered $400 \mathrm{mg} / \mathrm{kg} \mathrm{CE}$

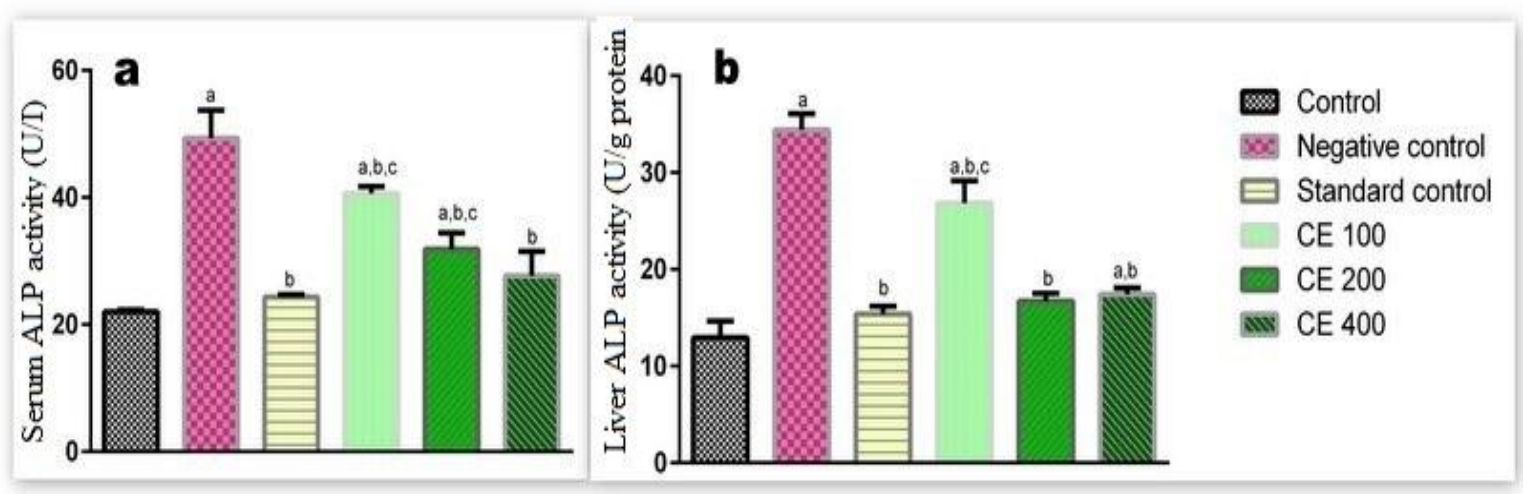

Figure 3: Effect of Cyperus esculentus milk extract on serum (a) and liver (b) ALP activity

aSignificant when compared with control at $p<0.05,{ }^{,}$Significant when compared to negative control at $p<0.05,{ }^{,}$Significant when compared to standard drug at $p<0.05$. Control: No treatment, Negative control: APAP 1 $\mathrm{g} / \mathrm{kg}$, Standard control: pre treated with 8.57mg/ kg Ascorbic acid, CE 100: pre administered $100 \mathrm{mg} / \mathrm{kg}$ CE, CE 200: pre administered $200 \mathrm{mg} / \mathrm{kg} \mathrm{CE}$, and CE 400: pre administered $400 \mathrm{mg} / \mathrm{kg}$ CE

\section{Effect of Cyperus esculentus milk on acetaminophen alterations of oxidative stress markers}

CE at the selected doses prevented decrease in serum GST activity caused by high dose acetaminophen $(p<0.05)$ to levels comparable $(p>0.05)$ to healthy untreated group (positive control) (Figure 4a). In the liver, there is a noticeable increase in GST activity of rats administered $100 \mathrm{mg} / \mathrm{kg}$ bw CE when compared with standard control (Figure 4b). There was notable increase $(p<0.05)$ in concentration of malondialdehyde in liver and serum of rats that were administered high dose acetaminophen, this effect was markedly mitigated in rats that were pre-administered extract at all selected doses. 


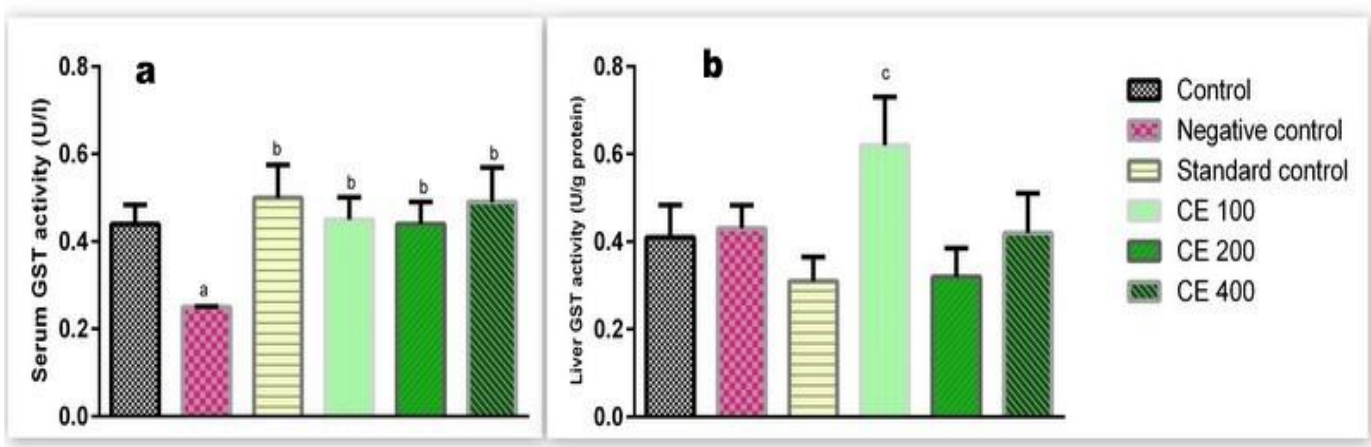

Figure 4: Effect of Cyperus esculentus milk extract on serum (a) and liver (b) glutathion-S- transferase activity

aSignificant when compared with control at $p<0.05$, ${ }^{b}$ Significant when compared to negative control at $p<0.05$, $c$ Significant when compared to standard drug at $p<0.05$. Control: No treatment, Negative control: APAP $1 \mathrm{~g} / \mathrm{kg}$, Standard control: pre treated with $8.57 \mathrm{mg} / \mathrm{kg}$ Ascorbic acid, CE 100: pre administered $100 \mathrm{mg} / \mathrm{kg}$ CE, CE 200: pre administered $200 \mathrm{mg} / \mathrm{kg}$ CE, and CE 400: pre administered $400 \mathrm{mg} / \mathrm{kg}$ CE

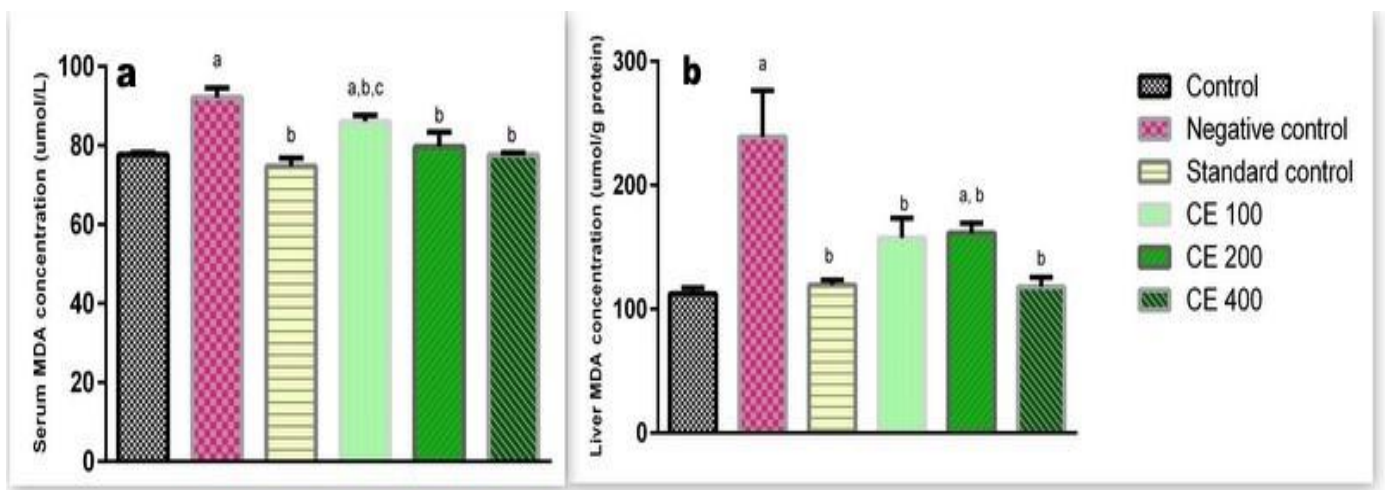

Figure 5: Effect of Cyperus esculentus milk extract on serum (a) and liver (b) Malondialdehyde concentration.

aSignificant when compared with control at $p<0.05,{ }^{b}$ Significant when compared to negative control at $p<0.05$, ${ }^{\circ}$ Significant when compared to standard drug at $p<0.05$. Control: No treatment, Negative control: APAP 1 $/ \mathrm{kg}$, Standard control: pre treated with $8.57 \mathrm{mg} / \mathrm{kg}$ Ascorbic acid, CE 100: pre administered $100 \mathrm{mg} / \mathrm{kg}$ CE, CE 200: pre administered $200 \mathrm{mg} / \mathrm{kg}$ CE, and CE 400: pre administered $400 \mathrm{mg} / \mathrm{kg}$ CE

Effect of Cyperus esculentus Milk Extract on Histopathology

Histopathology micrographs of liver sections of rats for the experimental groups are shown in Fig.6 A-F and they provide supportive evidence of result obtained from biochemical analysis. In this study, liver section from normal control rats (Fig. 6A - magnification under 10x) showed normal hepatoarchitecture and structural integrity of the liver, unremarkable portal veins, bile ducts and no signs for inflammation, necrosis or fibrosis or toxic changes. Liver section of rats from acetaminophen group (Fig. 6B - magnification under 10x) showed characteristics of hepatocellular damage, vacuolization of hepatocytes, mild sinusoidal dilation, fatty alterations, inflammation and necrosis. Pretreatment with Cyperus esculentus milk extract (Fig.6C, D, and E - magnification under 10x) and standard drug (Fig. 6F - magnification under 10x) showed recovery of the hepatocytes from necrosis and cellular damage indicating that the extract preserved the structural integrity of the liver and architecture of liver cells. This shows the potent hepatoproctective activity of the Cyperus esculentus milk extract. 

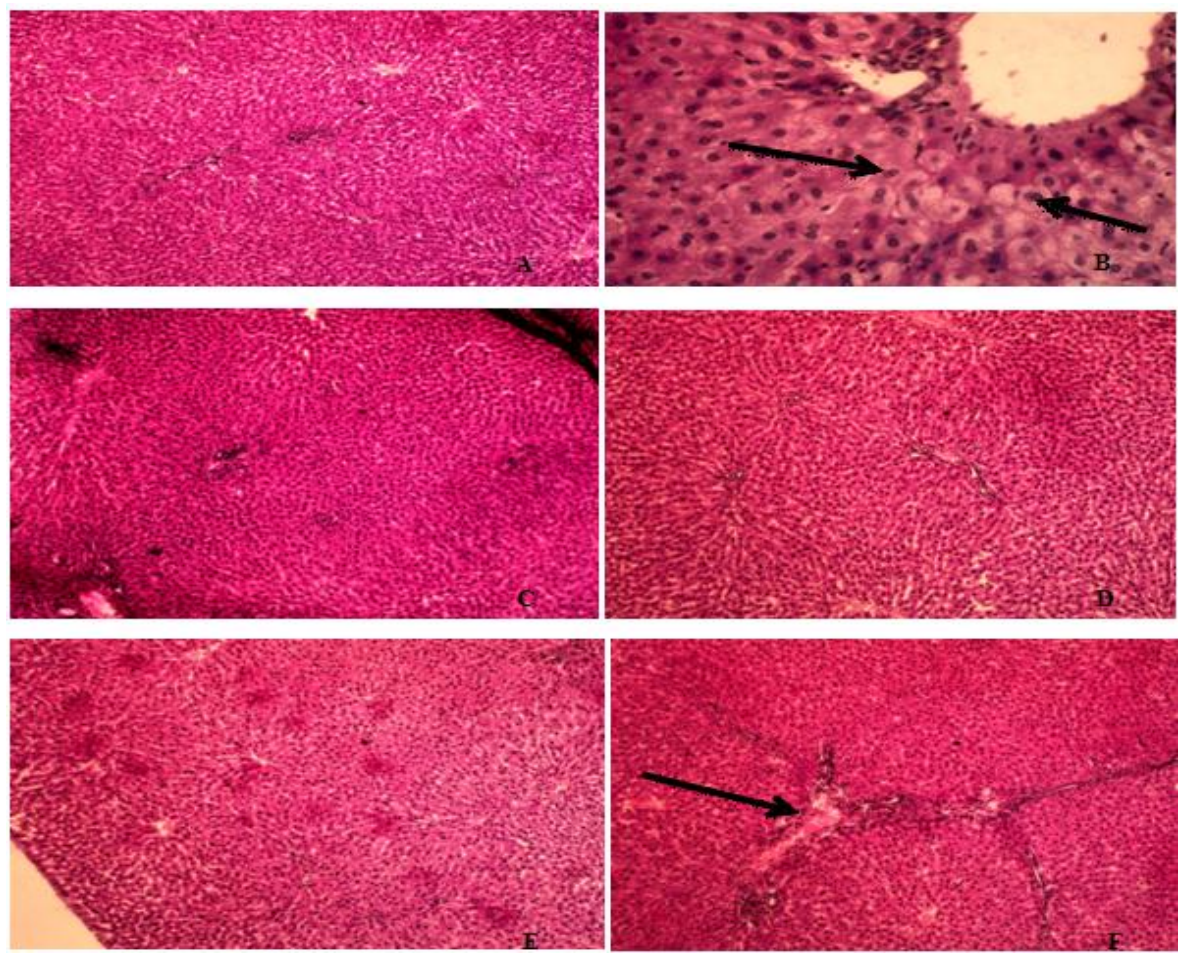

Figure 6: Liver Histopathology micrograms of experimental rats (10X)

Control: No treatment (A), Negative control: APAP $1 \mathrm{~g} / \mathrm{kg}(\mathbf{B})$, Standard drug: pre treated with $8.57 \mathrm{mg} / \mathrm{kg}$ Ascorbic acid (F), CE 100: pre administered $100 \mathrm{mg} / \mathrm{kg}$ CE (C), CE 200: pre administered $200 \mathrm{mg} / \mathrm{kg} \mathrm{CE} \mathrm{(D),} \mathrm{and} \mathrm{CE} \mathrm{400:} \mathrm{pre} \mathrm{administered} 400 \mathrm{mg} / \mathrm{kg}$ CE (E) NOTE: Arrow in B shows hydropic degeneration of the hepatocytes, i.e. the hepatocytes imbibe water. In $F$, the arrow points to peripheral mononuclear cell.

\section{DISCUSSION}

Effect of 21 days pre-administration of $C$. esculentus milk extract (CE) on high dose acetaminophen-induced liver toxicity was investigated. high dose acetaminophen $(1 \mathrm{~g} / \mathrm{kg})$ was hepatotoxic to rats as revealed by increased serum activities of AST, ALT, ALP, and concentration of MDA. The liver plays a pivotal role in biochemical transformation of xenogenous substances hence its susceptiblity to toxicity (Seif, 2016). Related to our findings, acetaminophen has been reported to produce hepatic necrosis at high doses (Mitchell et al., 1973; Arnaiz et al., 1995; Zaki, 2012).

Cyperus esculentus milk significantly decreased the elevated activities of serum ALT, AST and ALP in the serum, while the reverse scenario was observed in the liver. The release of aminotransferases is an outcome of impairment in cell membrane permeability and elevated synthesis of aminotransferases in the liver (ElSenosiy et al., 2015). The observed increase in activities of these enzymes in plasma of rats administered high dose acetaminophen is surmised to be a sign of hepatic injury. Some studies have reported similar effect of acetaminophen on serum liver enzyme activities (Cigremis et al., 2009; Ozer et al., 2008). Preadministration of CE may result in inactivation radical initiation pathways in the liver, which could possibly be attributed to some of the bioactive compounds present in the milk extract. AST is more found in mitochondria of hepatocytes and other tissues. ALT is more unique to liver and it is a better parameter for diagnosing liver impairments. Elevated serum ALP is also connected with liver cell impairment. The consequential elevation of serum AST, ALT and ALP activities as a result of acetaminophen 


\section{Nigerian Journal of Basic and Applied Science (June, 2019), 27(1): 105-113}

administration has been attributed to the disruption of structural integrity of the liver (Sallie et al., 1991). The observed decrease in liver enzymes activities in rats pre-administered $\mathrm{CE}$ can be attributed to abundance of bioactive phytochemicals in $C$. esculentus tuber extract. Similar effect has been reported in a related study by Onuoha et al., (2017). Phytochemical analysis of $C$. esculentus revealed its appreciable contents of flavonoids, alkaloids and saponins (Chukwuma et al., 2010). Some plant extracts were known to hold different levels of hepatoprotectiveness which depends mainly on the levels of bioactive compounds inherent in the plants (Sofowora, 1993).

GSTs are implicated in many diseases by virtue of their association with reduced glutathione levels in the tissues (Hayes et al., 2005). The high intracellular expression of GSTs makes them known biomarkers for monitoring impairments to cells of the soft tissues. Example, hepatocytes carry high level of a-GST, and serum a-GST which are known to be indicators of hepatocyte injuries (Becket et al., 1985; Hughes et al., 1997; Loguercio et al., 1998). CE markedly prevented acetaminophen mediated decreased serum GST activity. If there has been free radical involvement in acetaminophen toxicity, lipids peroxidation occur, directed to formation of malondialdehyde (MDA). Hence, MDA, a reactive aldehyde that causes toxic stress in cells and form covalent protein adducts is an important index of oxidative status (Janero, 1990; Farmer and Davoine, 2007). In this study, CE at selected doses minimizes the concentrations of malondialdehydein the liver and serum preventing the increased level observed in rats that were administered high dose acetaminophen. Our finding corroborate with Hassanein et al., (2011) who reported that Cyperus esculentus extract have commendable hepatoprotective effect on carbon tetrachloride model of hepatotoxicity. The nuts have also been suggested to hold the natural antioxidants needful for protection against free radical damage (Oyedepo, 2014). CE protective activity indicates that hepatic tissue damage was avoided and plasma membrane was stabilized. This could be adduced to presence bioactive phytochemicals in Cyperusesculentus nut (Moore, 1988). Histological architecture supported the finding that CE prevented the liver from damage by acetaminophen by establishing functional state of protein. The extent of hepatoprotection exhibited by CE against high dose acetaminophen could be attributed to its capacity to reduce harmful effects produced by the toxicant and restore the normal hepatic architecture.

\section{CONCLUSION}

In conclusion, the results of this study show that Cyperus esculentus milk extract may prevent high dose acetaminophen related liver impairment by decreasing serum liver enzymes activities (ALT, AST and ALP), and reducing processes that may be involved in production of free radicals. Therefore, Cyperus esculentus milk extract could be said to possess considerable hepato-protective efficacy.

\section{REFERENCES}

Adewusi, E. A., and Afolayan, A. J.(2010). A review of natural products with hepatoprotective activity. Journal of Medicinal Plants Research, 4(13):13181334.

Ahmed, J., and Ramaswamy, H. S. (2004). Microwave pasteurization and sterilization of foods. Food Science And Technology-New York-Marcel Dekker-, $167,691$.

Arafat, S. M., Gaafar, A. M., Basuny, A. M., Nassef, S. L. (2009). Chufa tubers (Cyperus esculentus L.): As a new source of food. World Applied Sciences Journal, 7(2): 151-156.

Arnaiz, S.L., Llesuy, S., Cutrín, J.C., Boveris, A. (1995). Oxidative stress by acute acetaminophen administration in mouse liver. Free Radical Biology and Medicine, 19:303-310. 
Beckett, G., Chapman, B., Dyson, E. and Hayes, J. (1985). Plasma glutathione Stransferase measurements after paracetamol overdose: evidence for early hepatocellular damage. Gut, 26: 26-31.

Buege, J.A. and Aust, S.D. (1978). Microsomal lipid peroxidation. In Methods in enzymology.Volume 52: Elsevier: 302310

Chukwuma, E.R., Obioma, N., Christopher, O.I. (2010). The phytochemical composition and some biochemical effects of Nigerian tigernut (Cyperus esculentus L.) tuber. Pakistan Journal of Nutrition, 9: 709-715.

Cigremis, Y., Turel, H., Adiguzel, K., Akgoz, M., Kart, A., Karaman, M., Ozen, H. (2009). The effects of acute acetaminophen toxicity on hepatic mRNA expression of SOD, CAT, GSH-Px, and levels of peroxynitrite, nitric oxide, reduced glutathione, and malondialdehyde in rabbit. Molecular and cellular biochemistry, 323: 31-38,

Couchman, F., Pinder, A. and Bromham, N. (1964). Studies on the essential oil of cyperus articulatus L. Tetrahedron, 20: 2037-2045,

Craig, D. G. N., Bates, C. M., Davidson, J. S., Martin, K. G., Hayes, P. C., Simpson, K. J. (2012). Staggered overdose pattern and delay to hospital presentation are associated with adverse outcomes following paracetamol-induced hepatotoxicity", British Journal of Clinical Pharmacology, 73:285-294.

El-Senosiy, Y.A., Ahmad, S.A., Farid, A.S. and Wessam, E. (2015). Hepatoprotective effect of asparagus racemosus in paracetamol induced hepatotoxicity in rats. Benha Veterinary Medical Journal, 28: 133-137.

Eteshola, E. and Oraedu, A. (1996). Fatty acid compositions of tigernut tubers (Cyperus esculentus L.), baobab seeds (Adansonia digitata L.), and their mixture.
Journal of the American Oil Chemists' Society, 73: 255-257.

Farmer, E.E., Davoine, C. (2007). Reactive electrophile species. Current opinion in plant biology, 10: 380-386.

Habig, W., Pabst, M.J., Jakoby, W.B. (1974). Glutathione-S-transferase: The first enzymatic step in mercapturic acid formation. Journal of Biological Chemistry, 249:130-137.

Hassanein, H., Nazif, N., Aboutabi, E., Hammouda, F. (2011). Solvent-Free microwave extraction and hepatoprotective activity of Cyperus eculentus L. and Cyperus articulatus essential oils. Journal of Applied Sciences Research, 7: 2455-2461.

Hassanein, H.M., Nazif, N. M., Aboutabl, E. A.and Hammouda, F. M. (2013). In-vitro hepatoprotection study, free radical scavenging activity and $\mathrm{gc} / \mathrm{ms}$ analysis of Cyperus esculentus essential oils from hydrodistillation and mae techniques. Planta Medica, 79: 38.

Hayes, J.D., Flanagan, J.U., Jowsey, I.R. (2005). Glutathione transferases. Annual Review of Pharmacology and Toxicology, 45:5188.

Hughes, V.F., Trull, A.K., Gimson, A., Friend, P.J., Jamieson, N., Duncan, A., Wight, D.G., Prevost, A.T. and Alexander, G. J. (1997). Randomized trial to evaluate the clinical benefits of seruma-glutathione Stransferase concentration monitoring after liver transplantation. Transplantation, 64:1446-1452.

Janero, D.R. (1990). Malondialdehyde and thiobarbituric acid-reactivity as diagnostic indices of lipid peroxidation and peroxidative tissue injury.Free Radical Biology and Medicine, 9: 515-540,

Loguercio, C., Caporaso, N., Tuccillo, C., Morisco, F., Blanco, G.D.V. and Blanco, C.D.V. (1998). Alpha-glutathione transferases in HCV-related chronic hepatitis: a new predictive index of 


\section{Nigerian Journal of Basic and Applied Science (June, 2019), 27(1): 105-113}

response to interferon therapy. Journal of hepatology, 28: 390-395.

Major, J. M., Zhou, E. H., Wong, H. L., Trinidad, J. P., Pham, T. M., Mehta, H., Ding, Y., Staffa, J. A., lyasu, S., Wang, C., Willy,M. E. (2016). Trends in rates of acetaminophen-related adverse events in the United States. Pharmacoepidemiology and Drug Safety, 25: 590-598.

Medina, J., Moreno-Otero, R. (2005). Pathophysiological basis for antioxidant therapy in chronic liver disease. Drugs, 65(17): 2445-61.

Mitchell, J., Jollow, D., Potter, W., Davis, D., Gillette, J., Brodie, B. (1973). Acetaminophen-induced hepatic necrosis. I. Role of drug metabolism. Journal of Pharmacology and Experimental Therapeutics, 187: 185-194.

Mokady, S. and Dolev, A. (1970). Nutritional evaluation of tubers of Cyperus esculentus L. Journal of the Science of Food and Agriculture, 21: 211-214.

Moore, M. (1988). Cytochemical responses of the lysosomal system and NADPHferrihemoprotein reductase in molluscan digestive cells to environmental and experimental exposure to xenobiotics.Marine Ecology Progress Series, 1:81-89.

Onuoha, N. O., Ogbusua, N. O., Okorie, A. N. and Ejike, C. E. (2017). Tigernut (Cyperus esculentus L.)"milk" as a potent "nutridrink" for the prevention of acetaminophen-induced hepatotoxicity in a murine model. Journal of intercultural ethnopharmacology, 6(3): 290-295.

Otto, A., Oliver, H., Jane, M. (1946). A method for the rapid determination of alkaline phosphatase with five cubic millimeters of serum. Journal of Biological Chemistry, 164:321-329.

Oyedepo, T. (2014). Hepatoprotective Activity of Annona muricata leaf extract against paracetamol induced hepatotoxicity. A Quarterly Publication of the Faculty of Science 1st ed Ede, State of Osun: Adeleke University, 1: 115-120.
Ozer, J., Ratner, M., Shaw, M., Bailey, W., Schomaker, S. (2008). The current state of serum biomarkers of hepatotoxicity. Toxicology, 245: 194-205.

Ozougwu, J. (2011). Herbal options for the management of drug induced liver damage: a review. Pharmacologyonline, 3:1481-1490.

Reitman, S., Frankel, S. (1957). A colorimetric method for the determination of serum glutamic oxalacetic and glutamic pyruvic transaminases",American journal of clinical pathology, 28: 56-63.

Sallie, R., Michael Tredger, J. and Williams, R. (1991). Drugs and the liver part 1: Testing liver function. Biopharmaceutics \& drug disposition, 12: 251-259.

Sánchez-Zapata, E., Fernández-López, J., Angel Pérez-Alvarez, J. (2012). Tiger nut (Cyperus esculentus) commercialization: health aspects, composition, properties, and food applications. Comprehensive Reviews in Food Science and Food Safety, 11: 366-377.

Seif, H. S. A. (2016). Physiological changes due to hepatotoxicity and the protective role of some medicinal plants. Beni-suef university journal of basic and applied sciences, 5: 134-146

Sofowora, A. (1993). Recent trends in research into African medicinal plants. Journal of ethnopharmacology, 38: 197-208.

Urban, M., Cagánovoá, B., Plačková, S., Kurcová, I., Pelclova, D. (2014). Paracetamol poisonings in the Czech and Slovak Republic and N-acetylcysteine treatment.Data analysis NeuroEndocrinology Letter, 35: 180-185.

Yang, Z., Ji, H., Liu, D. (2016). Oil biosynthesis in underground oil-rich storage vegetative tissue: comparison of Cyperus esculentus tuber with oil seeds and fruits. Plant and Cell Physiology, 16: 5-20.

Zaki, H. F. (2012). Potential protective effect of honey against paracetamol-induced hepatotoxicity. Archives Iranian Medicine, 15:674. 